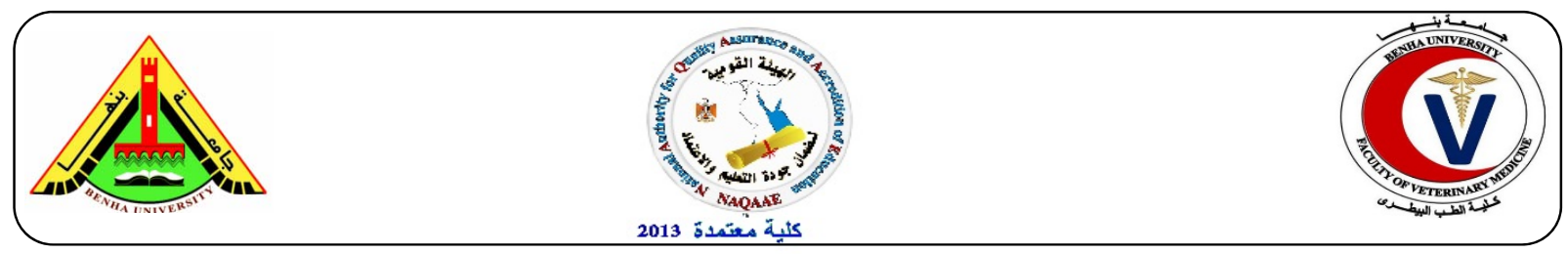

\title{
Bacteriological and molecular detection of brucellosis with special reference to the effect of disinfectants on isolated strains.
}

\author{
Lobna M. A. Salem ${ }^{1}$, Nashwa O. Khalifa ${ }^{1}$, Khoudair, R. M. ${ }^{2}$ and Samar M. M. Moustafa ${ }^{1}$ \\ ${ }^{1}$ Department of Zoonoses, Faculty of Vet. Med., Benha University. \\ ${ }^{2}$ Brucella Research Department, Animal Health Research Institute, Dokki. samar.mustafa@fvtm.bu.edu.eg
}

\section{A B S T R A C T}

A total of 127 specimens (13 aborted foeti, 46 milk samples, 37 lymph nodes, 14 livers, 14 spleen and 6 vaginal discharges) were collected and examined for isolation and typing of Brucella microorganism. The results detected 15 strains (5 aborted foeti, 4 milk, 5 lymph nodes and 1 spleen) were detected and typed as $B r$. melitensis biovar 3. Application of PCR test for rapid identification of Brucella strains which isolated from lymph nodes five of naturally infected animals (two cattle, one buffaloes, one sheep and one goat) revealed that all samples were reacted positively with $\mathrm{Br}$. melitensis specific DNA products with a molecular size of $731 \mathrm{pb}$. On sequencing, the Nucleotide sequence alignment of obtained sequences with other Brucella strain indicated that the obtained isolate have high identity with Br. melitensis biovar 3. The bacteriocidal activity of tested disinfectants against isolated Br. melitensis strain at variables concentration revealed that halogen showed highest bactericidal activity followed by QACs and phenolic while alkaline wasthe lowest effect.

Keywords: brucellosis, isolation, PCR, disinfectants sensitivity.

(http://www.bvmj.bu.edu.eg)

(BVMJ-31(1): 1-9, 2016)

\section{INTRODUCTION}

Brucellosis is a bacterial disease caused by members of the genus Brucella which is an important zoonosis that affects both humans and animals such as cattle, sheep, goats, dogs, and swine and the disease of economic significance in many developing countries (Al Dahouk et al., 2009). Brucellosis is diagnosed in the laboratory by using various techniques like microbiological isolation and identification which are the most reliable methods. However, these procedures are cumbersome and represent a great risk of infection for laboratory personnel (George and Araj, 2010). AMOS-PCR (Abortus, Melitensis, Ovis, Suis PCR) is the most efficient technique for diagnosis of Brucella at the species level and these useful methods applied to DNA extracted from a positive culture (Wareth et al., 2014). PCR-based genome sequence amplification method is a good alternative, as it allows for rapid identification of the bacteria. Differential identification of highly similar Brucella spp., however is only achievable with multiple gene sequence analyses (Tan et al., 2015). Disinfectant is extremely effective measure for successful brucellosis control especially in endemic area (Al-Majali et al., 2009). The present study was conducted to detect Brucella microorganism strains using bacteriological and molecular methods in different tissue specimens collected from different seropositive animal species and to evaluate the effect of disinfectants (quaternary ammonium compounds, halogen, Phenolic and alkaline) on isolated strains.

\section{MATERIAL AND METHODS:}

\subsection{Samples}

\subsubsection{Milk samples:}

46 milk samples were collected from different animal species (16 from cattle, 13 from buffaloes, 7 from sheep and 10 from goats). Twenty ml of milk were collected from udder of reactors cattle and goat into a sterile vacationer tube. Milk samples for bacteriological examination were stored at $4^{\circ} \mathrm{C}$ until used.

\subsubsection{Aborted foeti:}

The stomach contents of 13 aborted foeti (7cattle, 2buffaloes and 4 sheep) were collected according to Stableforth \& Galloway (1959). 


\subsubsection{Lymph nodes:}

37 lymph nodes (supramammary, internal iliac and retropharyngeal lymph nodes) were collected (9 from cattle, 4from buffaloes, 12 from sheep and 12 from goats). The technique for isolation of Brucella microorganisms from lymph nodes was done as follows: - The fat which covers the lymph nodes was trimmed off using sterile scissors. Lymph nodes were immersed in 95\% alcohol and put on to flame to allow alcohol to burn from the tissues. The lymph nodes were opened by scalpel and the internal surface was thoroughly minced. A piece of minced tissue was streaked over the surface of trypticase soy agar media. The inoculated plates were incubated at $37^{\circ} \mathrm{C}$ in $\mathrm{Co}_{2}$ incubator, and then examined after 4 days for Brucella growth.

\subsubsection{Liver and spleen samples:}

14 liver samples were collected (6 from cattle, 5 from buffaloes and 3 from sheep) \& 11 spleen samples ( 6 from cattle, 5 from buffaloes). Liver and spleen were trimmed carefully from the surrounding fat, were dipped in ethanol and burned with a flame to allow alcohol to burn the tissues then were placed in a sterile Pertri-dish and cut longitudinally with a sterile sharp scalpel, and the internal surface was thoroughly minced and rubbed over the surface of the medium. Plates were incubated at $37^{\circ} \mathrm{C}$ in $5-10 \%$ carbon dioxide incubator.

\subsubsection{Vaginal discharge:}

Six vaginal swabs were collected four from cattle and two from buffaloes using sterile cotton swabs.

\subsection{Bacteriological examination:}

\subsubsection{Isolation of Brucella micro-organisms:}

It was carried out on milk samples and different tissue specimens according to the methods recommended by Alton et al., (1988) on Trypticase soya agar media. The inoculated plates were incubated at $37^{\circ} \mathrm{C}$ in $\mathrm{Co}_{2}$ incubator, and examined after four days for Brucella growth.

\subsubsection{Identification and typing of Brucella isolates:}

Suspected isolated Brucella strains were identified and typed according to Alton et al., (1988).

\subsection{Molecular identification and biotyping of Brucella isolates}

PCR was carried out according to methods of Bricker and Halling (1994).

\subsubsection{Preparation of killed bacteria for PCR.}

When bacterial cells were used directly for PCR, All bacteria were killed by the addition of $67 \%$ methanol-33\% saline. The killed bacteria were rinsed one time in distilled water to remove the methanol and were then resuspended in distilled water at an optical density of 0.15 to 0.20 at 600 $\mathrm{nm}$ (approximately $10^{9}$ cells per $\mathrm{ml}$ ).

\subsubsection{Preparation of genomic DNA according to (Promega), USA.}

\subsubsection{DNA amplification by PCR assay.}

\subsubsection{Visualization of extracted DNA:}

Samples were electrophoresed on $1.5 \%$ agarose gel in $0.5 \mathrm{X}$ TBE buffer containing $0.5 \mu \mathrm{g} / \mathrm{ml}$ ethidium bromide for about 30-50 minutes at 70 volts using a minigel electrophoresis unit. DNA Bands were visualized on ultraviolet transilluminator. The molecular size of the DNA bands was compared with those of the $100 \mathrm{bp}$ DNA marker.

\subsection{Sequence and phylogenetic analysis:}

According to (Consumer protection Institute, Saxony Anhalt, Germany), the PCR products of Brucella samples were sequenced. Direct sequencing was carried out in both directions by termination cycle sequencing using the Big Dye Terminator Mix 1.1 (Applied Biosystems, Carlsbad, USA) with the same primers used for PCR product amplification. The assay was optimized by using a total reaction volume of 10 $\mu 1$. Briefly, for one reaction $1 \mu 1$ RNase-free water, $1 \mu \mathrm{l}$ of $5 \mathrm{x}$ Sequencing Buffer, $2 \mu \mathrm{l}$ Big Dye Terminator Mix 1.1 and $1 \mu \mathrm{l}$ of the according primer $(5 \mu \mathrm{M})$. The following thermal program was applied 1 cycle of $96^{\circ} \mathrm{C}$ for $1 \mathrm{~min}$ followed by 26 cycles of $95^{\circ} \mathrm{C}$ for $15 \mathrm{~s}, 53^{\circ} \mathrm{C}$ for $10 \mathrm{~s}$, and $60^{\circ} \mathrm{C}$ for $4 \mathrm{~min}$. After that, cycle sequencing products were purified with DyeEx 2.0 Spin Kit (QIAGENGmbh;, Hilden, Germany). The nucleotide sequences were resolved in an $\mathrm{ABI}$ 3130 Genetic Analyzer (Applied Biosystems, Carlsbad, USA).

\subsection{Phylogenetic Analysis}

Alignment of multiple nucleotide sequence $\mathrm{Br}$. melitensis isolates based on IS711a gene nucleotide data were done by using BioEdit program.

\subsection{Study the effect of disinfectants on isolated strains using minimum inhibition concentration (MIC).}

Bacterial preparation: was carried out according to Chapin and Lauderdale (2003).

Preparation of used disinfectants: was carried out according to manufacturer's instructions. 
Determination of MIC of used chemicals: it was carried out according Wang et al., (2015)

\section{RESULTS}

The isolation of Brucella organisms from tissue specimens of different animals species revealed that (15 strains) were isolated ( 5 from aborted foeti, 4 from milk, 5 from lymph nodes and 1 from spleen) as in Table (1). Typing of 15brucella isolates revealed that $\mathrm{Br}$. melitensis biovar 3 is the only strain excited among the examined animals Table (1). Application of PCR test for rapid identification of Brucella species in lymph nodes of five naturally infected animals two cattle, one buffaloes, one sheep and one goat revealed that five samples reacted positively to $\mathrm{Br}$. melitensis specific DNA products with a molecular size of $731 \mathrm{pb}$, indicative of $\mathrm{Br}$. melitensis DNA were obtained Figure (1). On sequencing, the Nucleotide sequence alignment of obtained sequences with other Brucella isolates Figure (2) indicated that the obtained isolate had higher identity with Brucella melitensis biovar 3 Figure (3). Concerning evaluation of the bactericidal activity of tested disinfectants against isolated $\mathrm{Br}$. melitensis strains at different variables concentration revealed that halogen had the highest bactericidal activity followed by QACs and phenolic while Alkaline showed the lowest bactericidal effect.

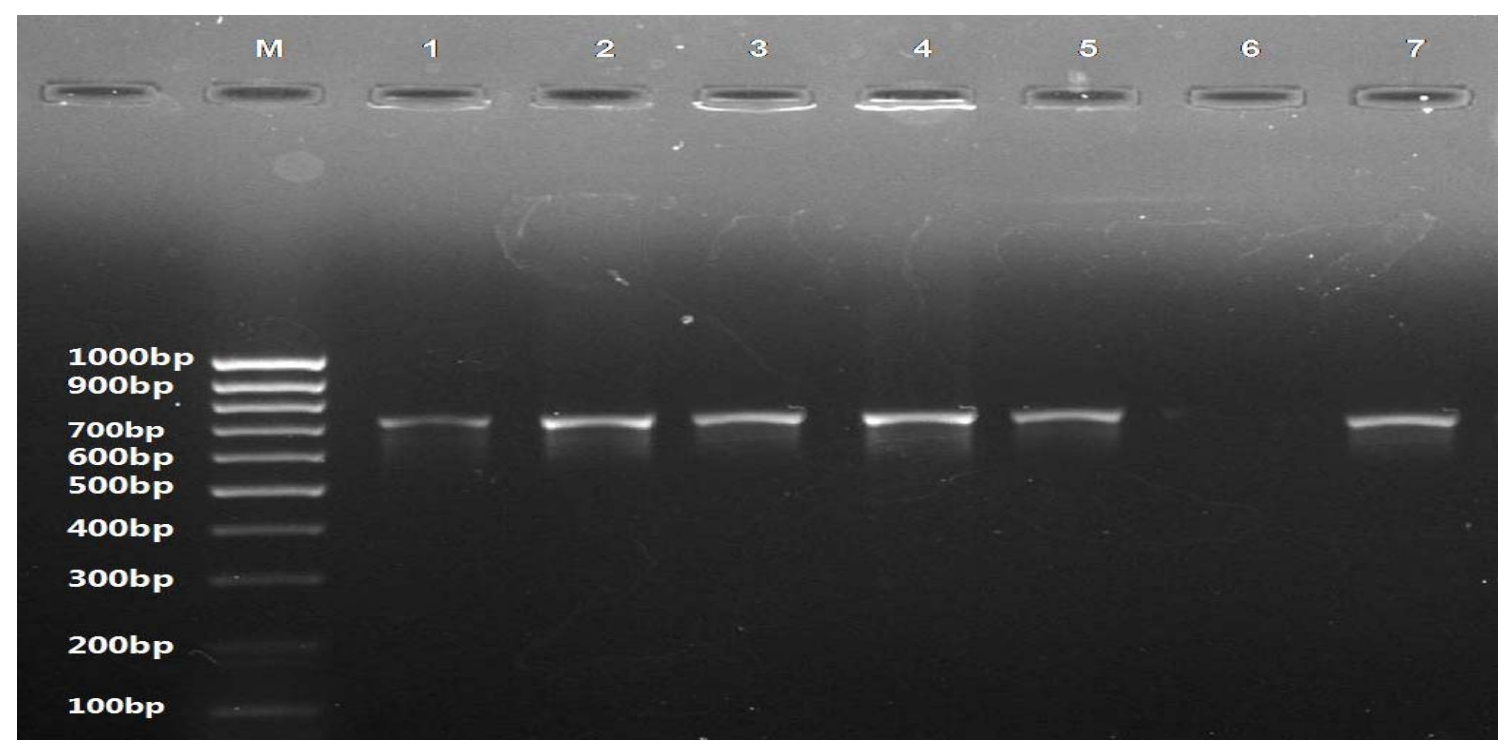

Figure (1): Amplified product of Brucella melitenses $731 \mathrm{bp}$ stained with $2 \%$ eithidium bromide. (M) Represents a 100-bp DNA ladder as a size standard. (Lanes 1-2) +ve colony isolated from cattle. (Lane 3) from buffaloes, (Lane 4) from sheep. (Lane 5) from goats. (Lane 6) -ve control. (Lane 7) +ve control (Br. melitensis).

TTCGGCTCAGAATAATCCACAGAAGGTAGAGCAGTAATATCCAATAGACGCCATTAACAATAG CGAGATTGGAATAGCTTACCCGCCAATCTTCGCCCTGCCACCAGCCAATAACGGCAATTATCGC TGTCACTGTTGCAAGTATGGCAGCGAGCGCTCTAGCGTGACGAAGCACTGTCTTTCTGACAATT TCCAGATTCACCCCTAGGGCGTGTCTGCATTCAACGTAACCAGATCATAGCGCATGCGAGATGG ACGAAGCCCATGAATGCGGTCAATGTTTTCTCGCATCGCAGCGCAATA.

Figure (2). Nucleotide sequence of isolated Brucella melitensis. 
Salem et al. (2016). BVMJ-31(1): 1-9

\begin{tabular}{|c|c|}
\hline ucellam & ................ \\
\hline tensis 17711 partial sequence & AAATCGCGTCCTTGCTGG. T. A.T.AGT.TT. A AC. AC. . C. TCGAT.TCGT. \\
\hline Srucella melitensis bv 3 complete sequence & \\
\hline AJ271968.1| Brucella abortus & $A G G C \ldots C G G C T C A G, T C A \ldots G T \ldots A, C C A, C A, G$ \\
\hline gbJJX081250.1| Bricella or & $C A G C A, A G C C C G, A, G, C A G C$. \\
\hline irucella melitensis this study & AATAGCGAGATTGGAATAGCTTACCCGCC. AATCTTCGCCCTGCCACCAGCCAATAACG \\
\hline Srucella melitensis IS711 partial sequence & 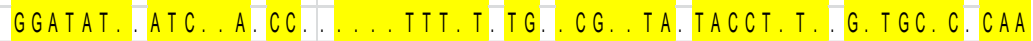 \\
\hline Frucella melitensis bv. 3 comp & $\ldots \ldots \ldots$ \\
\hline AJ271968.1| Brucella abortus & AT, AG.T, GAAT, . TT, TTT, A. AGTTGA. \\
\hline gb|JX081250.1||Brucellac & . CCT, .T.G.GA, GCAG., A.TGC.T.TG.CCATTGA. \\
\hline Brucella melitensis this study & 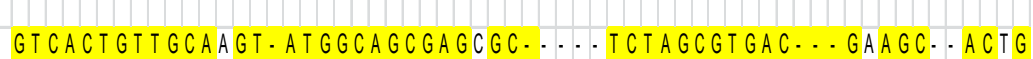 \\
\hline Srucella melitensis IS711 partial s & $\ldots T T \ldots A C, T \ldots A, C G C \ldots T C A T \ldots A, \cdots C, A . A, T, A G \ldots C, \cdots T \cdots G G \ldots$ \\
\hline Brucella melitensis b & $\ldots \ldots \ldots \ldots \ldots \ldots \ldots$ \\
\hline AJ271968.1| Brucella abortus & 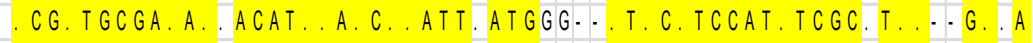 \\
\hline gb|JX081250.1||Brcella ovis IS711 & $A C A, T A A G, A G T$. AA. AAT, C. GAG. .TTTGGGT.T.C.TT. AGAAGAA.GTTTGGT. T \\
\hline ellame & GATT......CACCCC. TAGGGCGTGTCTGCATTCAACGTAACCAGATCAT..AGCGCA \\
\hline Brucella melitensis Is & 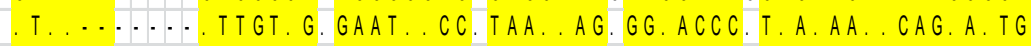 \\
\hline nce & \\
\hline AJ271968.1| Brucella abortus & ATGCAGA.......... \\
\hline gb|JX081250.1||Brcella ovis IS711 & AC. . TAAGCATTTTA. TA.. AAATTA. \\
\hline ella me & CAT. GAATGCGGTCAATGTTTTCTCGCATCGCAGCGCAA \\
\hline Brucella melitensis IS711 partia & 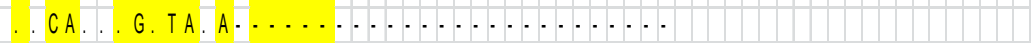 \\
\hline Brucella melitensis & $\ldots \ldots \ldots \ldots \ldots \ldots \ldots \ldots \ldots$ \\
\hline AJ271968.1| Brucella abortus & 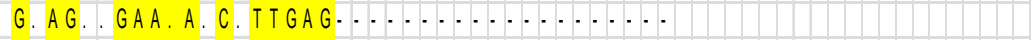 \\
\hline gb|JX081250.1|| Brceella ovis S7711 & 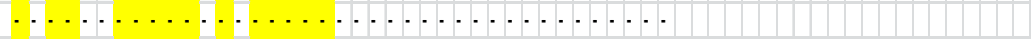 \\
\hline
\end{tabular}

Figure ( 3) . Nucleotide sequence alignment of obtained sequences with other Brucella isolates from GenBank database.

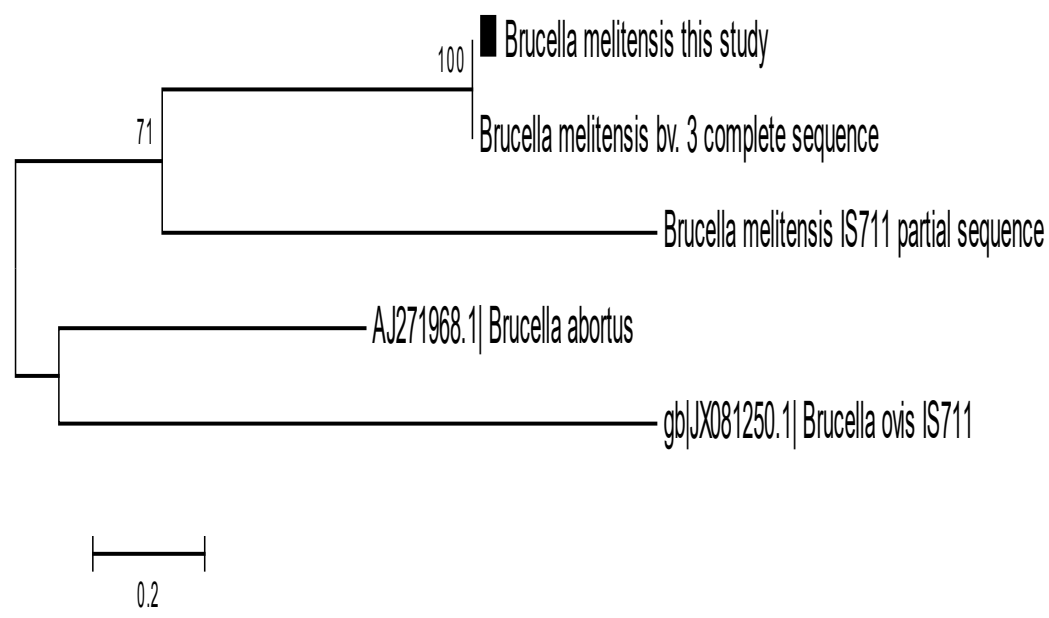

Figure (4): Phylogenetic tree of different Brucella strains based on the nucleotide sequences of the IS711 gene by using neighbour-joining methods in MEGA6 software 
Bacteriological and molecular detection of brucellosis

Table (1) Isolated Brucella strains and their biotype from different animal species.

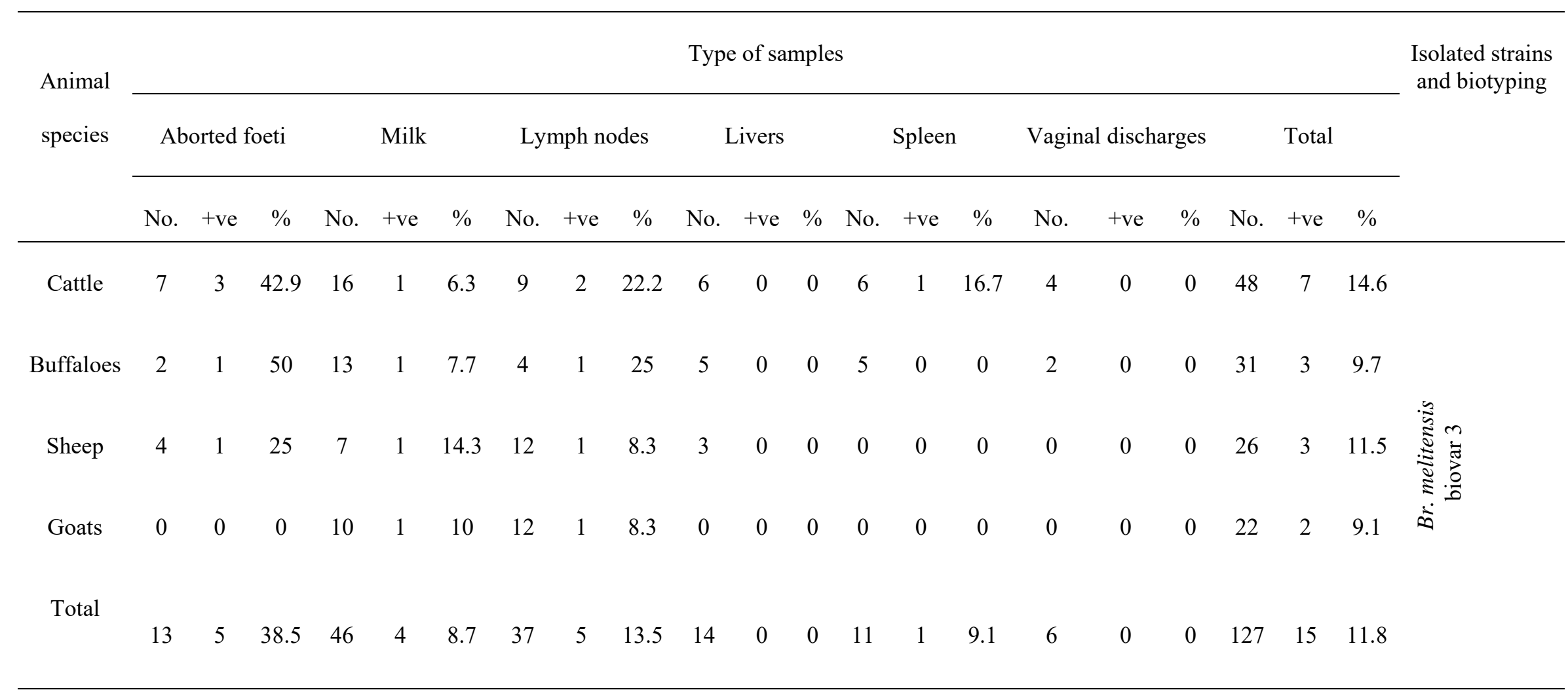


Salem et al. (2016). BVMJ-31(1): 1-9

Table (2): Sensitivity of Brucella melitensis strains to disinfectants using (MIC).

\begin{tabular}{|c|c|c|c|c|c|c|c|c|c|c|}
\hline \multirow{2}{*}{ Disinfectant } & \multirow{2}{*}{$\begin{array}{l}\text { Contact } \\
\text { time }\end{array}$} & \multicolumn{9}{|c|}{ Dilution } \\
\hline & & $10^{-1}$ & $10^{-2}$ & $10^{-3}$ & $10^{-4}$ & $10^{-5}$ & $10^{-6}$ & $10^{-7}$ & $10^{-8}$ & $10^{-9}$ \\
\hline QACs & $20 \mathrm{~min}$ & - & - & - & - & + & + & + & + & + \\
\hline Phenolic & $20 \mathrm{~min}$ & - & - & - & - & + & + & + & + & + \\
\hline Alkaline & $20 \mathrm{~min}$ & - & - & - & + & + & + & + & + & + \\
\hline
\end{tabular}


Table (3): Oligonucleotide primers used for Brucella DNA amplification

\begin{tabular}{|c|c|c|c|}
\hline $\begin{array}{l}\text { Primer } \\
\text { code }\end{array}$ & Primer sequences & Product size & Species specificity \\
\hline IS711-SP & 5'TGCCGATCACTTAAGGGCCTCAT-3` & $498 \mathrm{bp}$ & \multirow{3}{*}{$\begin{array}{l}\text { B. Abortus(biotype } \\
1,2 \text { \& 3) } \\
\text { B. melitensis }\end{array}$} \\
\hline Ba-sp & 5 '-GACGAACGGAATTTTTCCAATCCC-`3 & & \\
\hline Bm-sp & 5'AAATCGCGTCCTTGCTGGTCTGA-3’ & $731 \mathrm{bp}$ & \\
\hline
\end{tabular}

\section{DISCUSSION}

Animals of all ages are susceptible to brucellosis but the disease occurs most commonly in sexually mature animals particularly in dairy animals. The organism has marked predilection for ruminant placenta, fetal fluids, mammary glands and joints. Unknown factors in the gravid uterus, collectively called allontoic fluid actors, stimulate the growth of Brucella. Erythritol, a four carbon alcohol is considered to be one of these factors. High concentrations of erythritol are present in fetal tissues as well, which are the sites of infection establishment (Radostits et al., 2007). In this study, 15 strains of Brucellea were recovered from different samples collected from cattle, buffaloes, sheep and goats.

Typing of isolates according to Alton et al., (1975) resulted in finding Br. melitensis Biovar (3) is the serotype existed in examined animals. Similar findings were reported by many authors as Ammar (2000), Montasser et al., (2001), Lobna (2006), Abd El-Hamid (2007), Samaha et al., (2008), Khoudair et al., (2009), Afifi et al., (2011) ,Manal (2011), Amin et al., (2012) and ElShymaa(2014) who were isolated Brucella melitensis biotype 3 from different animals species in Egypt. The reason of isolation of Brucella melitensis biovar 3 from cattle and buffaloes may be attributed to the nearly constant close contact during raising with infected sheep and goats. These findings have a great epidemiological importance as Brucella melitensis is more dangerous for human than other brucella species. PCR assay can simultaneous detect and differentiate of $\mathrm{Br}$. abortus and Br. melitensis in the same time and one reaction (Mirnejad et al., 2012).

The isolated brucella species from positive reactors animals were examined with multiplex conventional PCR for detection and identification of $\mathrm{Br}$. abortus and $\mathrm{Br}$. melitensis. The obtained results revealed amplification only with $B r$. melitensis. The results of application of (PCR) assay for rapid identification of brucella species in the lymph nodes of (5) naturally infected animals (2cattle, 1buffaloes, 1sheep and 1 goats) showed that 5 samples reacted positively with $\mathrm{Br}$. melitensis biovar (3) specific DNA products with a molecular size of $731 \mathrm{bp}$, indicative of $\mathrm{Br}$. melitensis DNA were obtained as shown in Figure (1).

The obtained results were agreed with that reported previously by Ilhan et al. (2008) and ElShymaa (2014) who recorded that PCR products with a molecular size of $731 \mathrm{bp}$ indicative of $\mathrm{Br}$. melitensis DNA. Also these results were similar to that obtained by Al-Bayatti and Al-Thwan (2009) who mentioned that is due to many advantages, like speed, safety, high sensitivity and specificity, PCR is recommended to use in diagnosis of animal brucellosis. In the same way, the obtained results were similar to that recorded by Simone et al. (2007) who reported that microbiological culture depends on organism viability, quality of the sample, contamination of the sample with other microorganisms and time between collection and analysis, also it is pathogenic to human while DNA detection by means of PCR does not depend on these factors. It can detect few number as $10^{4}$ bacteria in sample.

Application of molecular assays may usefully provide high sensitivity and specificity as well as speed for genotyping. This Multiplex PCR in Brucella species was first used in USA. (Halling et al., 1993). In this study, DNA sequence analysis of fragment $\mathrm{OMP}$ gene of $\mathrm{Br}$. melitensis (PCR product) was performed by clone manager software. This program was used in matching in order to obtain the full length of nucleotide sequence data (Figure 2). Figure (3) showed Nucleotide sequence alignment of obtained sequences with other Brucella isolates from Gen Bank database and revealed that the sequence of the obtained isolate have high identity with $\mathrm{Br}$. melitensis biovar 3 and showed heterogenitz with other brucella strains such as $\mathrm{Br}$. abortus and $\mathrm{Br}$. ovis. The result concluded that, the obtained isolate is Br. melitensis biovar 3. According to Dale et al., (2003) the homology level of an isolate was called homolog if the homology level more than $60 \%$. In 
this work, Figure (4) revealed that there was a close relationship with $\mathrm{Br}$. melitensis biovar 3 and Brucella melitensis IS711. In addition, $\mathrm{Br}$. melitensis and $\mathrm{Br}$. melitensis biovar 3 located together in separate clades. Furthermore, sequences belonging to the brucella clearly cluster together; while strains of other Brucellea $(\mathrm{Br}$. abortus and $\mathrm{Br}$. ovis) are displayed by a separated outlier and this obviously showed the higher degree of similarity and genetic relationship among Brucella strains. Results in table (2) showed the bactericidal activity of tested disinfectants against isolated Br.melitensis strains at different variables concentration revealed to the highest bactericidal activity was recorded with halogen followed by QACs and phenolic while the lowest bactericidal effect was recorded in Alkaline. These results were similarly to previous results of (Wanke, 2004) and (Wang et al., 2015) which concluded that halogens, quaternary ammonium compound, phenolic, and alkaline could be selected for disinfection to control brucellosis.

It can be concluded that: The isolation and biotyping of $\mathrm{Br}$. melitensis particularly biovar 3 . PCR assay could be recommended as confirmatory methods and an alternative to culture for diagnosis of brucellosis as its speed, safety, high sensitivity, specificity and saving cost and time. Also Quaternary ammonium compound (QACs), Halogen (chlorine), phenolic and Alkaline (sodium hydroxide) are disinfectants of choice for the control of brucellosis.

\section{REFERENCES}

Abd El-Hamid, N. H. 2007. Studies on brucellosis in sheep and goats. MVSc., Thesis (Infectious Diseases), Faculty of Veterinary Medicine, Cairo University.

Afifi, M. M., AbdalRaouf, Y.M., El-Bayoumy, E.M., Montasser, A.M., Mohamed, H.A. 2011. Isolation of biotyping of $\mathrm{Br}$. melitensisi from Upper Egypt. J. Amer. Sci., 7(3): 653-659.

Al-Bayatti, S.A., Al-Thwan, A.N. 2009. Evaluation of PCR, ELISA, and Culture Methods for the Diagnosis of Animal Brucellosis. Diyala Agricultural Sciences Journal, 1(1): 1-17.

Al-Dahouk, S., Neubauer, H., Hensel, A., Schoneberg, I., Nockler, K. Alpers, K., Merzenich, H., Stark. K. 2009.Changing epidemiology of brucellosis, Germany, 1962-2005. Emerg Infect Dis.13:18951900.
Al-Majali, A.M.; Talafha, A.Q.; Ababneh, M.M; Ababneh, M.M. 2009.Seroprevalence and risk factors for bovine brucellosis in Jordan. J. Vet. Sci; 10(1): 61-65.

Alton, G., Jones, L., Angus, R., Verger, J. 1988. Techniques for the brucellosis laboratory. Institut National de la Recherché Agronomique, Paris.

Alton, G.; Jones, L.; Pietz, D. 1975. Laboratory techniques in brucellosis. WHO Geneva. offset publ. 55: 145-148.

Amin, M.M., Ahmed, S.A., Zaki, H.M., Ismail R.I. 2012. Serological and molecular studies on the diagnosis of bovine brucellosis. Nature and Science, 10 (11): 68-76.

Ammar, K.M. 2000. Some epidemiological aspects of bovine, ovine and caprine brucellosis in Egypt. SCVMJ, III(1): 145-156.

Bricker, B.J. , Halling, S.M. 1994.Differentiation of brucella abortus bv. 1, 2, and 4, B. melitensis, B. ovis and B.suis bv. 1 by PCR. Journal of clinical Microbiology, Nov. 1994, 2660-2666, Vol32, No.11.

Chapin, K. C., Lauderdale, T. 2003. Reagents, stains, and media: bacteriology, p. 358. In P. R. Murray, E. J. Baron, J. H. Jorgensen, M. A. Pfaller, and R. H. Yolken (ed.), Manual of Clinical Microbiology, 8th ed. ASM Press, Washington, D.C.

Dale, J.W., Schantz, M.V. , Klena, J.D. 2003. From genes to genomes. John Wiley \& Sons Ltd. England.

El-Shymaa, A. A. 2014 Recent techniques for diagnosis of brucellosis in farm animals. MVSc, Thesis, Infectious diseases, Faculty of Vet. Med, Zagazig University.

George, F., Araj, M. 2010.Update on laboratory diagnosis of human brucellosis Inte. J. Antimicrobial Agents. 36S: S12-S17.

Halling, S.M., Tatum, F.M., Bricker, B.J. 1993. Sequence and characterization of an insertion sequence IS711, from Brucella ovis. Gene, 133: 123-127.

Iihan, Z., Aksakal, A., Ekin, H. I., Gulhan, T., Solmaz, H., Erdenlig, S. 2008. Comparison of culture and PCR for the detection of Brucella melitensis in blood and lymphoid tissues of serologically positive and negative slaughtered sheep. Letters in Applied Microbiology. 46: 301-306.

Khoudair, R.M., Ibrahim, E.M., Saker, G.G., Hafez, M.A. 2009. Clinico diagnostic and pathological studies on cattle and buffaloes suffering from brucellosis and tuberculosis in Kafr El Sheikh Governorate. Egypt. J. Comp. Path. \& Clinic. Path. 22(1): 148-174 
Lobna, M. A. 2006. Epidemiological studies on Brucellosis in animal and man with special reference to prevention and control. Ph.D. Thesis, Zoonosis, Fac. Vet. Med., Benha University.

Manal, E.M., El-Newishy, A.M, Hussein, M.N, EL-Ged, A.M.S, EL-Basionny, A.A, ELOlamy, G.M. 2011. Serological studies of man on animal brucellosis in Sherkia governorate. Benha Vet. Med. J. [II]: 23-35

Mirnejad, R., Doust, R.H., Kachuei, R., Mortazavi, S.M., Khoobdel, M. , Ahamadi, A. 2012. Simultaneous detection and differentiates of B. abortus and B. melitensis by combinatorial PCR. Asian Pac J Trop Med. 5(1):24-8.

Montasser, A.M., Hamdy, M.E., EL-Biomy, E.M. Khoudier, R. M. 2001. Bacteriological profile of Brucella isolated from cattle in Egypt. $6^{\text {th }}$ Sci. Cong., Egyptian Society for Cattle Diseases., 4-6 Nov:163-170. Assiut,Egypt

Radostits, O. M., Gay C. C., Hinchcliff, K.W., Constable, P.D. 2007. Veterinary Medicine. 10th ed. Elsevier Saunders, London. 389390.

Samaha, H., Al-Rowaily, M., Khoudair, R.M., Ashour, H.M. 2008. Multicenter Study of Brucellosis in Egypt. Emerg. Infect. Dis., 14 (12): 1916-1918.
Simone, M., Eliana S., Rosa M.P., Fabiola R.C., Airton V., Lara B.K., Ricardo A.D., Margareth E.G. 2007. Detection of Brucella abortus DNA in illegal cheese from sio pailo and minas gerais and differentiation of b19 vaccinal strain by means of the polymerase chian reaction (PCR). Brazilian Journal of Microbiology, 38: 17-22.

Stableforth, A.W., Galloway, I.A. 1959. Infectious Disease of animals. Disease due to bacteria. $1^{\text {st }}$ ed. Butter Worth, scientific publications, London, England.

Tan, K., Tan,Y., Chang, L., Lee,K.W., Nore1,S.,Yee,W., Isa, M., Jafar, F.L., Hoh, C., AbuBaka, S. 2015. Full genome SNPbased phylogenetic analysis reveals the origin and global spread of Brucella melitensis. BMC Genomics 16:93

Wang, Z.; Bie,P.F.; Cheng, J.; Wu, Q.M. ;Lu, L. 2015. In vitro evaluation of six chemical agents on smooth Brucella melitensis strain. Annals of Clinical Microbiology and Antimicrobials 14:16.

Wanke, M. M. 2004. Canine brucellosis. Review. Anim Reprod Sci 82-83: 195-207.

Wareth, G., Hika, A., Refai, M., Melzer, F., Roesler, U., Neubauer, H. 2014. Animal brucellosis in Egypt. J Infect Dev Ctries; 8(11):1365-1373. 